\title{
Conserved number of U2 snDNA sites in Piabina argentea, Piabarchus stramineus and two Bryconamericus species (Characidae, Stevardiinae)
}

\author{
Diovani Piscor ${ }^{1}$, Carlos Alexandre Fernandes ${ }^{2}$ and Patricia P. Parise-Maltempi ${ }^{1}$
}

The chromosomal location of 5S rRNA and U2 snRNA genes of Piabina argentea, Piabarchus stramineus and two Bryconamericus species from two different Brazilian river basins were investigated, in order to contribute to the understanding of evolutionary characteristics of these repetitive DNAs in the subfamily Stevardiinae. The diploid chromosome number was $2 \mathrm{n}=52$ for Bryconamericus $\mathrm{cf}$. iheringii, Bryconamericus turiuba, Piabarchus stramineus and Piabina argentea. The 5S rDNA clusters were located on one chromosome pair in P. stramineus and B. cf. iheringii, and on two pairs in $B$. turiuba and $P$. argentea. The U2 snDNA clusters were located on the one pair in all species. Two-color FISH experiments showed that the co-localization between 5S rDNA and U2 snDNA in P. stramineus can represent a marker for this species. Thus, the present study demonstrated that the number of U2 snDNA clusters observed for the four species was conserved, but particular characteristics can be found in the genome of each species.

Keywords: Repetitive DNA, Splicing, 5S rDNA, Chromosome, Diploid number.

A localização cromossômica dos genes de RNAr 5S e RNAsn U2 de Piabina argentea, Piabarchus stramineus e duas espécies de Bryconamericus provenientes de duas bacias hidrográficas foi investigada, com a intenção de contribuir com o entendimento de características evolutivas destes DNAs repetitivos na subfamília Stevardiinae. O número cromossômico diploide foi $2 \mathrm{n}=52$ para Bryconamericus $\mathrm{cf}$. iheringii, Bryconamericus turiuba, Piabarchus stramineus e Piabina argentea. Os sítios de DNAr $5 \mathrm{~S}$ foram localizados em um par cromossômico em $P$. stramineus e $B$. cf. iheringii, e em dois pares em $B$. turiuba e $P$. argentea. Os sítios de DNAsn U2 foram localizados em um par em todas as espécies. Experimentos de FISH com duas sondas mostraram que a co-localização entre os DNAr 5S e DNAsn U2 em P. stramineus pode representar um marcador para esta espécie. Portanto, o presente estudo demonstrou que o número de sítios de DNAsn U2 observado para as quatro espécies foi conservado, porém características particulares podem ser encontradas no genoma de cada espécie.

Palavras-chave: DNA repetitivo, DNAr 5S, Cromossomo, Número diploide. Splicing.

\section{Introduction}

Numerous modifications have been made regarding the phylogenetic relationships of the genera Bryconamericus Eigenmann, 1907, Piabarchus Myers, 1928 and Piabina Reinhardt, 1867, which have already belonged to the group incertae sedis in Characidae by Lima et al. (2003), as well as many other genera. Nevertheless, studies based on analyses of molecular characters have indicated that Bryconamericus, Piabarchus and Piabina belong to the subfamily Stervadiinae (see, for example, Oliveira et al., 2011; Thomaz et al., 2015).

The karyotype and chromosomal characteristics of Bryconamericus, Piabarchus and Piabina have been described in the literature by some authors utilizing conventional (Giemsa staining, silver staining, C-banding) and molecular (Fluorescence in situ hybridization - FISH with rDNA and snDNA probes) cytogenetic techniques (data summarized in Tab. 1). In these studies, the most frequently reported diploid number was $2 \mathrm{n}=52$ chromosomes and variations involving the number of clusters of $18 \mathrm{~S}$ and $5 \mathrm{~S}$ rDNA were also registered.

Unlike rDNAs, U2 snDNA clusters have been poorly investigated in chromosomes of Bryconamericus, Piabarchus and Piabina genera. To date, only studies in B. ecai da Silva, 2004 and Bryconamericus sp. showed chromosomal mapping of U2 snDNA in this fish group (Santos et al., 2017). The chromosomal mapping of U2 snDNA clusters

${ }^{1}$ Instituto de Biociências, Departamento de Biologia, Laboratório de Citogenética, Universidade Estadual Paulista "Júlio de Mesquita Filho" (UNESP), Av. 24A, 1515, 13506-900 Rio Claro, SP, Brazil. (DP) plusmoi_pis@yahoo.com.br, @https://orcid.org/0000-0002-2375-5997 (corresponding author), (PPPM) parise@rc.unesp.br

${ }^{2}$ Universidade Estadual de Mato Grosso do Sul (UEMS), Unidade de Mundo Novo, BR 163, Km 20.2, $79980-000$ Mundo Novo, MS, Brazil. fxande@gmail.com 
showed a broad scenario in fish chromosomes, with these sequences accumulating in one or more chromosome pairs. In B. ecai, Bryconamericus sp. (Santos et al., 2017), Astyanax mexicanus (De Filippi, 1853) (Piscor et al., 2016) and $A$. jordani (Hubbs \& Innes, 1936) (Silva et al., 2015) signals in one chromosome pair were detected. On the other hand, eleven Astyanax Baird \& Girard, 1854 species showed two chromosomes pairs bearing U2 snDNA clusters (Silva et al., 2015; Piscor et al., 2016). The authors showed that, in comparison to other repetitive sequences studied in chromosomes of Bryconamericus and Astyanax, the U2 snDNA is the most conserved.
Although scarce, the mapping of U2 snDNA sequences in different individuals has demonstrated that these sequences may be linked with other multigene families. According to Yano et al. (2017), in four Triportheus Cope, 1872 species, the U2 snRNA genes are syntenic with both rDNAs (18S and 5S), while in Triportheus albus Cope, 1872, the U2 snRNA genes are syntenic with $18 \mathrm{~S}$ rDNA and in other three Triportheus species, the U2 snRNA genes are not syntenic with rDNAs. The last described pattern is common in fish (Pelliccia et al., 2001; Manchado et al., 2006; ÚbedaManzanaro et al., 2010; Utsunomia et al., 2014; Scacchetti et al., 2015; Silva et al., 2015).

Tab. 1. Literature review on the number of chromosomes bearing repetitive sequences in Piabina, Piabarchus and Bryconamericus genera from Brazilian rivers. ${ }^{\mathrm{a} C y t o t y p e s ;}{ }^{\mathrm{b}}$ Diploid numbers; ${ }^{\mathrm{c}}$ Extra chromosome; ${ }^{\mathrm{d}} 18 \mathrm{~S}$ rDNA cluster numbers; ${ }^{5} 5 \mathrm{~S}$ rDNA cluster numbers ${ }^{\mathrm{f}} \mathrm{U} 2 \mathrm{snDNA}$ cluster numbers; $\mathrm{MG}=$ State of Minas Gerais; $\mathrm{MS}$ = State of Mato Grosso do Sul; PR = State of Paraná; RS = State of Rio Grande do Sul; SP = State of São Paulo.

\begin{tabular}{|c|c|c|c|c|c|c|}
\hline Genera/Species & Localities/States & $2 \mathrm{n}^{\mathrm{b}}$ & $18 \mathrm{~S}^{\mathrm{d}}$ & $5 \mathrm{~S}^{\mathrm{e}}$ & $\mathrm{U} 2^{\mathrm{f}}$ & References \\
\hline \multicolumn{7}{|c|}{ Bryconamericus } \\
\hline B. aff. exodon & Três Bocas Stream (PR) & 52 & 8 & - & - & Paintner-Marques et al. (2002) \\
\hline B. aff. iheringii & Água Floresta River (PR) & 52 & 2 & - & - & Paintner-Marques et al. (2003) \\
\hline$B$. aff. iheringii cyt- $\mathrm{I}^{\mathrm{a}}$ & Maringá Stream (PR) & 52 & 6 & - & - & \multirow{3}{*}{ Capistano et al. (2008) } \\
\hline$B$. aff. iheringii cyt-II ${ }^{\mathrm{a}}$ & Keller River (PR) & 52 & 10 & - & - & \\
\hline$B$. aff. iheringii cyt-III ${ }^{\mathrm{a}}$ & Tatupeba Stream (PR) & 52 & 2 & - & - & \\
\hline B. ecai cyt- $\mathrm{I}^{\mathrm{a}}$ & Forquetinha River (RS) & 52 & 4 & - & - & \multirow{4}{*}{ Santos et al. (2012) } \\
\hline B. ecai cyt-II ${ }^{\mathrm{a}}$ & Forquetinha River (RS) & 52 & 2 & - & - & \\
\hline B. ecai cyt-III ${ }^{\mathrm{a}}$ & Forquetinha River (RS) & $52+\mathrm{B}^{\mathrm{c}}$ & 6 & - & - & \\
\hline B. ecai cyt-IV & Forquetinha River (RS) & 52 & 2 & - & - & \\
\hline B. turiuba & Tributary of Passa-Cinco River (SP) & 52 & 4 & 4 & - & \multirow{2}{*}{ Piscor et al. (2013) } \\
\hline B. cf. iheringii & Tributary of Corumbataí River (SP) & 52 & 2 & 2 & - & \\
\hline B. aff. iheringii cyt- $\mathrm{I}^{\mathrm{a}}$ & Três Bocas Stream (PR) & 52 & 2 & - & - & \multirow{6}{*}{ Silva et al. (2014) } \\
\hline$B$. aff. iheringii cyt- $\mathrm{II}^{\mathrm{a}}$ & Três Bocas Stream (PR) & 52 & 8 & - & - & \\
\hline$B$. aff. iheringii cyt-III ${ }^{\mathrm{a}}$ & Três Bocas Stream (PR) & 52 & 6 & - & - & \\
\hline$B$. aff. iheringii cyt-IV & Três Bocas Stream (PR) & 52 & 6 & - & - & \\
\hline$B$. aff. iheringii cyt- $\mathrm{V}^{\mathrm{a}}$ & Três Bocas Stream (PR) & 52 & 8 & - & - & \\
\hline B. aff. iheringii cyt-VI ${ }^{\mathrm{a}}$ & Três Bocas Stream (PR) & 52 & 8 & - & - & \\
\hline B. aff. iheringii & Ocoí River (PR) & 52 & 2 & - & - & Nishiyama et al. (2015) \\
\hline B. ecai cyt- $\mathrm{V}^{\mathrm{a}}$ & Forquetinha River (RS) & 52 & 4 & 6 & 2 & \multirow{6}{*}{ Santos et al. (2017) } \\
\hline B. ecai cyt-VI ${ }^{\mathrm{a}}$ & Forquetinha River (RS) & 52 & 13 & 8 & 2 & \\
\hline B. ecai cyt-VII ${ }^{\mathrm{a}}$ & Forquetinha River (RS) & 52 & 10 & 7 & 2 & \\
\hline Bryconamericus sp. (Group 1) & Vermelho River (PR) & 52 & 4 & 6 & 2 & \\
\hline Bryconamericus sp. (Group 2) & Vermelho River (PR) & 52 & 16 & 8 & 2 & \\
\hline Bryconamericus sp. (Cambuta) & Cambuta River (PR) & 52 & 6 & 2 & 2 & \\
\hline B. turiuba & Tributary of Passa-Cinco River (SP) & 52 & - & 4 & 2 & \multirow{2}{*}{ Present study } \\
\hline B. cf. iheringii & Tributary of Corumbataí River (SP) & 52 & - & 2 & 2 & \\
\hline \multicolumn{7}{|c|}{ Piabarchus stramineus } \\
\hline P. stramineus & Guaçu Stream (MS) & 52 & 2 & 2 & - & \multirow{2}{*}{ Piscor et al. (2013) } \\
\hline P. stramineus & Guaçu Stream (MS) & 52 & - & 2 & 2 & \\
\hline \multicolumn{7}{|c|}{ Piabina } \\
\hline P. argentea & São Francisco River (MG) & 52 & 6 & 4 & - & Peres et al. (2008) \\
\hline P. argentea & Municipality of Itatinga (SP) & 52 & 2 & 4 & - & \multirow{4}{*}{ Pazian et al. (2012) } \\
\hline P. argentea & Municipality of Botucatu (SP) & 52 & 4 & 4 & - & \\
\hline P. argentea & Municipality of Bauru (SP) & 52 & 6 & 6 & - & \\
\hline P. anhembi & Municipality of Salesópolis (SP) & 52 & 2 & 2 & - & \\
\hline P. argentea & Tributary of Passa-Cinco River (SP) & 52 & - & 4 & 2 & Present study \\
\hline
\end{tabular}


The aim of the present study was to analyze the chromosomal location of two multigene families $(5 \mathrm{~S}$ rDNA and U2 snDNA) in the genome of Piabina argentea Reinhardt, 1867, Piabarchus stramineus (Eigenmann, 1908) and two Bryconamericus species, in order to obtain a better knowledge about the relationship among U2 snRNA and 5S rRNA genes of species of the subfamily Stevardiinae.

\section{Material and methods}

All institutional guidelines for the care and use of laboratory animals were followed. Animals were captured with the permission of the Instituto Chico Mendes de Conservação da Biodiversidade (ICMBio; number 23434-1).

Two Bryconamericus species, Piabarchus stramineus and Piabina argentea were obtained from locations in Brazil as follows: seven individuals of $B$. turiuba Langeani, Lucena, Pedrini \& Tarelho-Pereira, 2005 (five males and two females) and five B. cf. iheringii (Boulenger, 1887) (all males) from a tributary of the Passa-Cinco River and a tributary of the Corumbataí River (Corumbataí River basin, State of São Paulo), respectively; twenty-one individuals of $P$. stramineus (12 males and nine females) from Guaçu Stream (Iguatemi River basin, State of Mato Grosso do Sul); and eleven individuals of $P$. argentea (five males and six females) from a tributary of the Passa-Cinco River (Corumbataí River basin, State of São Paulo). Voucher specimens were deposited in the fish collection of the Laboratório de Citogenética (LC), Universidade Estadual Paulista, SP, Brazil, as B. turiuba (LC 1421), B. cf. iheringii (LC 1424), $P$. stramineus (LC 1502), and $P$. argentea (LC 1074). Chromosomes were obtained as described by Foresti et al. (1981) and chromosome morphologies were determined according to the arm ratios (Levan et al., 1964).

Genomic DNA was extracted from fin and liver samples of Bryconamericus and Piabina species according to Sambrook, Russell (2001). The 5S rDNA probe was prepared using polymerase chain reaction (PCR) with primers described by Pendás et al. (1994) (A, 5'-TAC

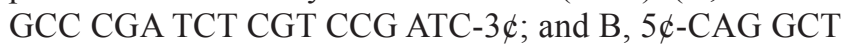
GGT ATG GCC GTA AGC-3 $\not$ ). The U2 snDNA probe was prepared using PCR with primers described by Bueno et al. (2013) (U2F, 5'-ATC GCT TCT CGG CCT TAT G-3'; and U2R, 5'-TCC CGG CGG TAC TGC AAT A-3'). The 5S rDNA probes were labeled by PCR with biotin14-dATP (Invitrogen, San Diego, CA, USA), and the U2 snDNA probes were labeled by PCR with digoxigenin11-dUTP (Roche, Mannheim, Germany). Probes labeled with digoxigenin-11-dUTP were detected using antidigoxigenin-rhodamine (Roche, Mannheim, Germany), and probes labeled with biotin-14-dATP were detected using Alexa Fluor 488 conjugated streptavidin (Invitrogen, San Diego, CA, USA). Single and two-color FISH experiments were performed using mitotic metaphase chromosomes according to Pinkel et al. (1986) with modifications described by Cabral-de-Mello et al. (2010). Chromosomes were counterstained with Vectashield Mounting Medium (Vector, Burlingame, CA, USA) containing DAPI (4',6-diamidino2-phenylindole). Chromosomes and fluorescent signals were visualized with an Olympus BX51 microscope coupled to a digital camera (Olympus model D71).

\section{Results}

The diploid chromosome number was $2 \mathrm{n}=52$ for Piabarchus stramineus (karyotype formula: $6 \mathrm{~m}+10 \mathrm{sm}+$ $16 \mathrm{st}+20 \mathrm{a})$, Bryconamericus turiuba (karyotype formula: $8 \mathrm{~m}+10 \mathrm{sm}+14 \mathrm{st}+20 \mathrm{a})$, B. cf. iheringii (karyotype formula: $10 \mathrm{~m}+14 \mathrm{sm}+18 \mathrm{st}+10 \mathrm{a})$, and Piabina argentea (karyotype formula: $6 \mathrm{~m}, 8 \mathrm{sm}, 24 \mathrm{st}$ and 14a). These data were reported in previous studies by Piscor et al. (2013) for Bryconamericus species and Piscor et al. (2017) for $P$. argentea. The 5S rDNA clusters were observed on the pericentromeric regions of one acrocentric pair in $B$. cf. iheringii, one submetacentric pair in $P$. stramineus, two acrocentric pairs in B. turiuba and two pairs in $P$. argentea (one acrocentric and one subtelocentric) (Fig. 1).

The U2 snDNA clusters were observed on the pericentromeric regions of the long (q) arm of one chromosome pair in all four species under study: on the submetacentric pair in Bryconamericus turiuba and Piabarchus stramineus and on the subtelocentric pair in B. cf. iheringii and Piabina argentea (Fig. 1). The $P$. stramineus species showed 5S rDNA and U2 snDNA clusters on the same chromosome in adjacent position, while for $B$. cf. iheringii, B. turiuba, and $P$. argentea these clusters are found on separate chromosomes (Fig. 1).

The chromosomes bearing U2 snDNA clusters observed in present study are summarized in Fig. 2.

\section{Discussion}

In two Bryconamericus species, Piabarchus stramineus and Piabina argentea under study, as well as shown by Santos et al. (2017), the U2 snDNA clusters were observed on the interstitial/pericentromeric regions of the long arm of one chromosome pair in all species, except fo Bryconamericus sp. (Cambuta River) that showed one pair bearing U2 snDNA clusters in interstitial position on the short arm. These observations make it clear that, regardless of chromosomal positions, the number of U2 snDNA sites is conserved for Bryconamericus genus, as well as described for Astyanax genus (Silva et al., 2015; Piscor et al., 2016). However, in Astyanax genus almost all species showed two pairs bearing U2 snDNA sites. The location of U2 snRNA gene is described here for the first time in Piabina argentea. Thus, in the future, extending these observations to other Piabina species could help us confirm if in the genus the number of clusters of this gene is also conserved. 

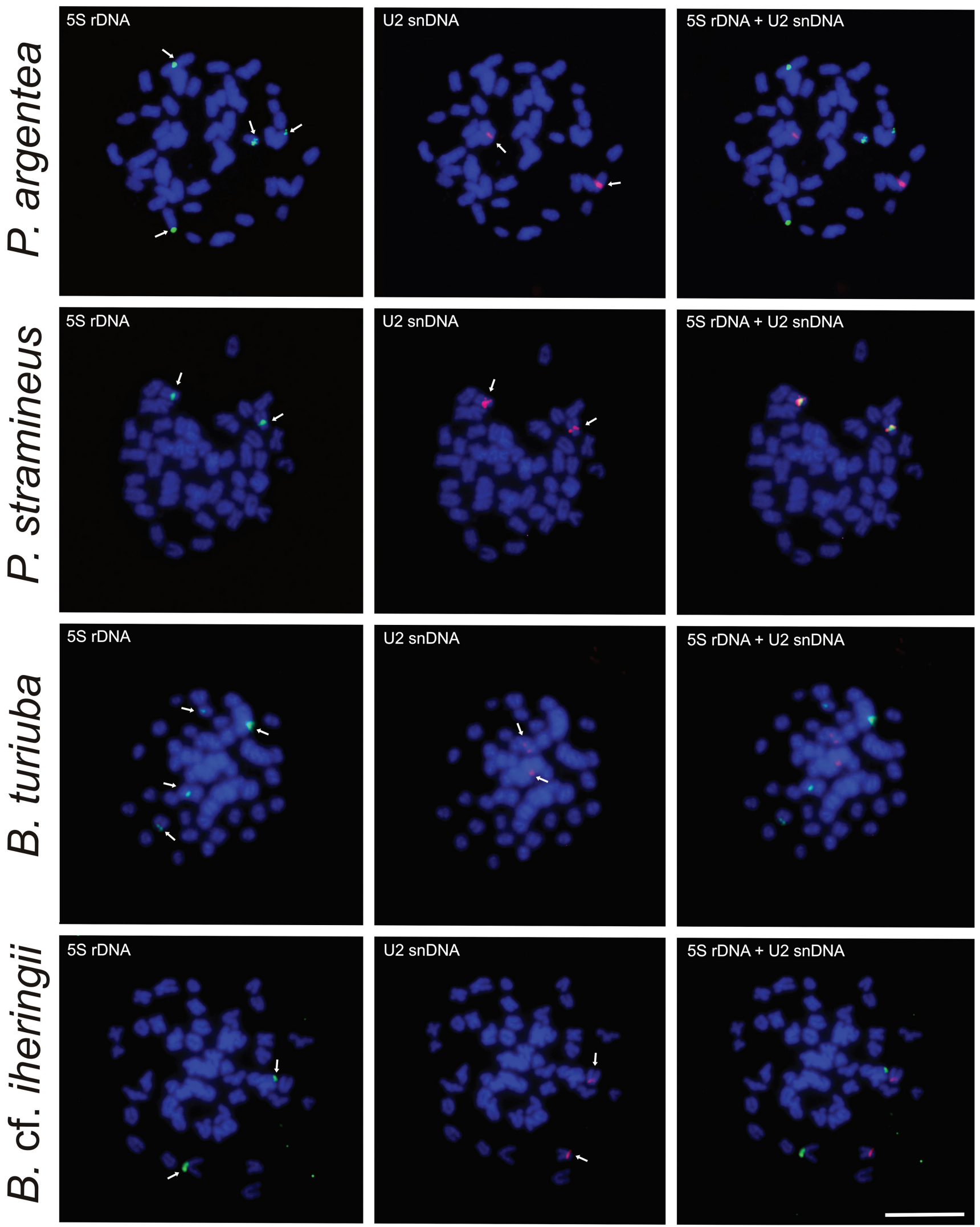

Fig. 1. Sequential metaphases of the chromosomal locations of U2 snDNA and 5S rDNA clusters using two-color FISH in species of the genera Piabina, Piabarchus and Bryconamericus. The arrows indicate the fluorescent signals. Note that, in P. stramineus, the two repetitive DNA are located adjacently on the same pair. Scale bar $=10 \mu \mathrm{m}$. 

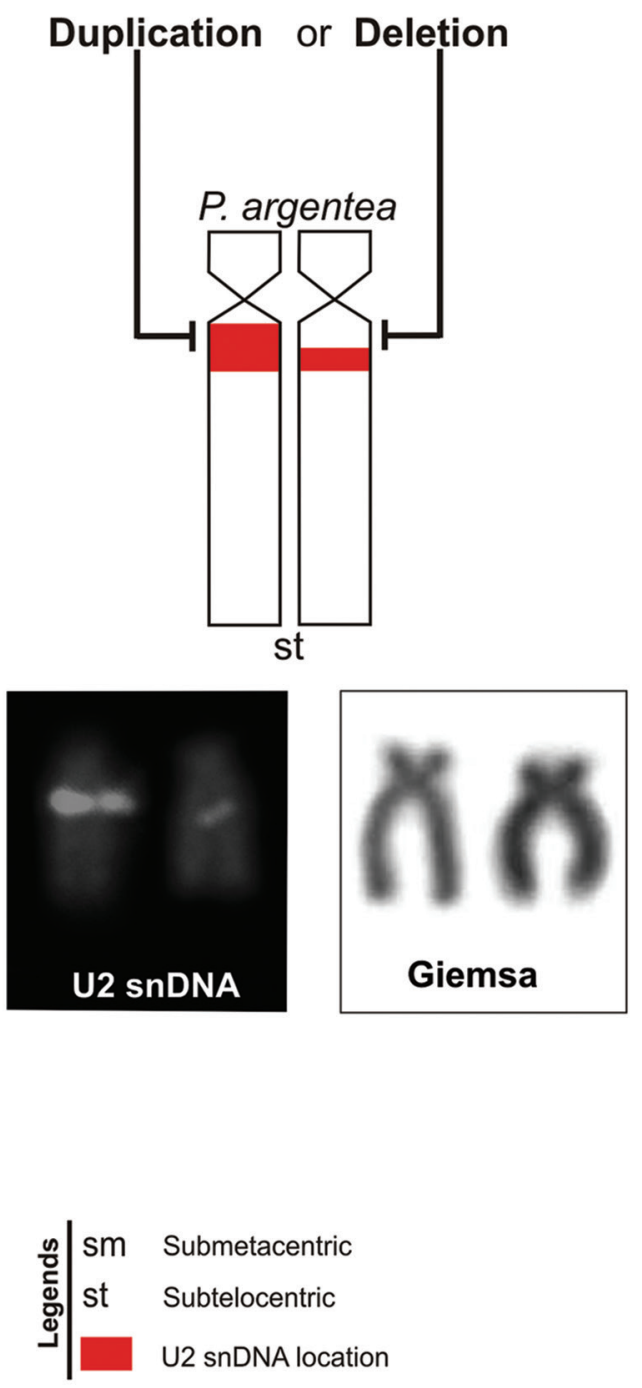

\section{P. stramineus}
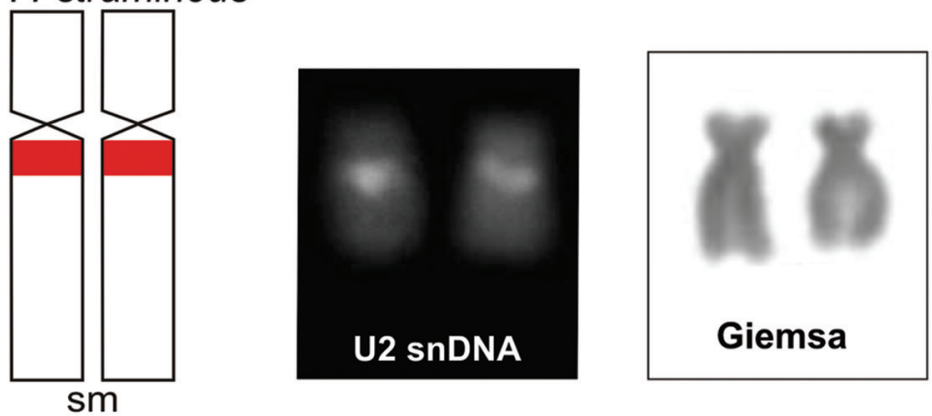

\section{B. turiuba}
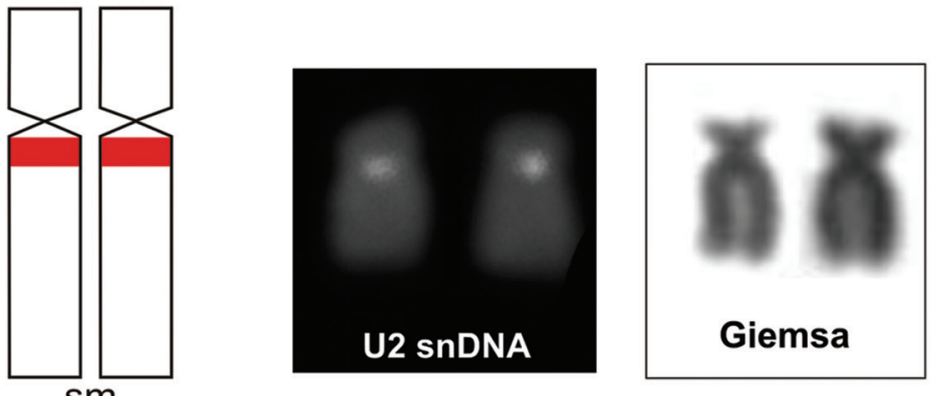

$\mathrm{sm}$
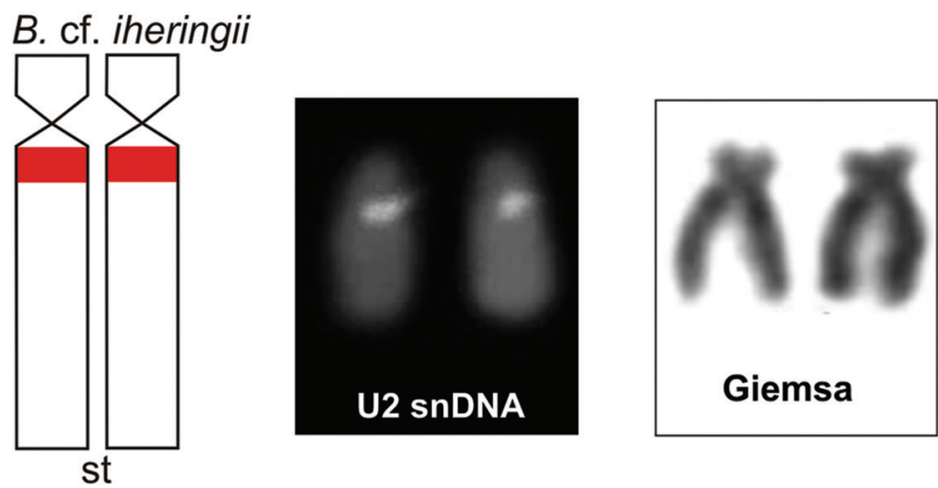

U2 snDNA

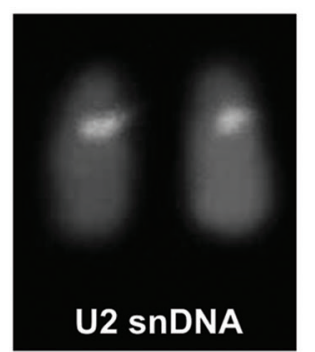

Fig. 2. Scheme showing the number of $\mathrm{U} 2 \mathrm{snDNA}$ sites on the real pairs and ideograms in species of the genera Piabina, Piabarchus and Bryconamericus. Note the size heteromorphism of U2 snDNA clusters between homologous chromosomes in P. argentea.

In Piabina argentea, a size heteromorphism of U2 snDNA was detected between homologous chromosomes of males and females, indicating that this polymorphism has no association with sex and reflects differences in the number of U2 snDNA copy among one and another homologues chromosome. This attribute suggests that rearrangement processes occurred during meiosis, as e.g., deletion or duplication of these segments. Chromosomal rearrangements tend to be most common in specific regions or "hotspots", and deletions and/or duplications of single-base pairs typically arise during homologous recombination (Clancy, Shaw, 2008). Similar results were reported by Carvalho, Dias (2007), which verified an interindividual size heteromorphism of 18S rDNA clusters in Iheringichthys labrosus (Lütken, 1874) (Pimelodidae).
The karyotypes of Bryconamericus turiuba, B. cf. iheringii and Piabina argentea shared the non-syntenic sites of $5 \mathrm{~S}$ rDNA and U2 snDNA in their genomes, a common characteristic of several fish groups (Supiwong et al., 2013; Utsunomia et al., 2014; Piscor et al., 2016). On the other hand, in Piabarchus stramineus, the U2 snDNA and 5S rDNA clusters were found in adjacent positions. This syntenic organization of these clusters were not observed in the other species studied here, demonstrating that co-localization between 5S rDNA and U2 snDNA in P. stramineus seems to represent a derived condition and could be used as a marker for this species.

A similar example of co-localization between the $5 \mathrm{~S}$ and $18 \mathrm{~S}$ rDNA (on the pair 24) was verified for Bryconamericus cf. iheringii (Piscor et al., 2013), however these clusters presented telomeric location, while co-localization between 
5S rDNA and U2 snDNA in Piabarchus stramineus under study were observed on the pericentromeric regions. According to Schweizer, Loidl (1987), the proximity of telomeric regions within interphase nuclei would facilitate genetic material transfer, as predicted by Rabl's model. Therefore, the pericentromeric location of the $5 \mathrm{~S} \mathrm{rDNA} /$ U2 snDNA clusters in $P$. stramineus would not facilitate transference events, as suggested by Piscor et al. (2013) for $B$. cf. iheringii. Thus, probably this co-localization in $P$. stramineus could be explained by association between these multigene families and mobile elements, common association in distinct groups for different repetitive DNAs (Cioffi et al., 2010; Nakajima et al., 2012; Anjos et al., 2015).

Other repetitive sequences were studied near 5S rDNA clusters in other fish groups, e.g., in Astyanax, the 5S rDNA was observed co-located to GATA repeats in four species [Astyanax lacustris (Lütken 1875) $(=$ A. altiparanae Garutti \& Britski, 2000), A. fasciatus (Cuvier, 1819), A. marionae Eigenmann, 1911 and A. schubarti Britski, 1964] (Piscor, Parise-Maltempi, 2016). The authors believe that the 5S-GATA co-location can have been maintained in different Astyanax species because represents an evolutionary advantage (Piscor, Parise-Maltempi, 2016).

In general, our study showed that one chromosome pair bearing U2 snDNA clusters was conserved for the two genera (Bryconamericus and Piabina) of the subfamily Stevardiinae, with non-syntenic organization of 5S rDNA and U2 snDNA in their genomes, except for Piabarchus stramineus that presented a derived condition (co-localization).

\section{Acknowledgments}

The authors are grateful to Dr. Francisco Langeani Neto and Dr. Ricardo Britzke by species identifications. This study was supported by Coordenadoria de Aperfeiçoamento de Pessoal de Nível Superior (CAPES).

\section{References}

Anjos A, Ruiz-Ruano FJ, Camacho JPM, Loreto V, Cabrero J, Souza MJ, Cabral-de-Mello DC. U1 snDNA clusters in grasshoppers: chromosomal dynamics and genomic organization. Heredity [serial on internet]. 2015; 114:207-19. Available from: https:// doi.org/10.1038/hdy.2014.87

Bueno D, Palacios-Gimenez OM, Cabral-de-Mello DC. Chromosomal mapping of repetitive DNAs in Abracris flavolineata reveal possible ancestry for the B chromosome and surprisingly $\mathrm{H} 3$ histone spreading. PLoS One [serial on internet]. 2013; 8(6):e66532. Available from: https://doi. org/10.1371/journal.pone.0066532

Cabral-de-Mello DC, Moura RC, Martins C. Chromosomal mapping of repetitive DNAs in the beetle Dichotomius geminatus provides the first evidence for an association of $5 \mathrm{~S}$ rRNA and histone $\mathrm{H} 3$ genes in insects, and repetitive DNA similarity between the B chromosome and A complement. Heredity [serial on internet]. 2010; 104:393-400. Available from: https://doi.org/10.1038/hdy.2009.126
Capistano TG, Portela-Castro ALB, Júlio Jr. HF. Chromosome divergence and NOR polymorphism in Bryconamericus aff. iheringii (Teleostei, Characidae) in the hydrographic systems of the Paranapanema and Ivaí Rivers, Paraná, Brazil. Genet Mol Biol. 2008; 31(1):203-07.

Carvalho RA, Dias AL. Interindividual size heteromorphism of NOR and chromosomal location of 5S rRNA genes in Iheringichthys labrosus. Braz Arch Biol Technol [serial on internet]. 2007; 50(1):141-06. Available from: http://dx.doi. org/10.1590/S1516-89132007000100017

Cioffi MB, Martins C, Bertollo LAC. Chromosome spreading of associated transposable elements and ribosomal DNA in the fish Erythrinus erythrinus. Implications for genome change and karyoevolution in fish. BMC Evol Biol [serial on internet]. 2010; 10(271):1-9. Available from: https://doi. org/10.1186/1471-2148-10-271

Clancy S, Shaw K. DNA deletion and duplication and the associated genetic disorders. Nat Educ. 2008; 1(1):23. Available from: https://www.nature.com/scitable/topicpage/dna-deletion-andduplication-and-the-associated-331

Foresti F, Almeida-Toledo LF, Toledo-Filho SA. Polymorphic nature of nucleolus organizer regions in fishes. Cytogenet Cell Genet [serial on internet]. 1981; 31(3):137-44. Available from: http://dx.doi.org/10.1159/000131639

Levan A, Fredga K, Sandberg AA. Nomenclature for centromeric position on chromosomes. Hereditas [serial on internet]. 1964; 52(2):201-20. Available from: https://doi. org/10.1111/j.1601-5223.1964.tb01953.x

Lima FCT, Malabarba LR, Buckup PA, Pezzi da Silva JF, Vari RP, Harold A, Benine R, Oyakawa OT, Pavanelli CS, Menezes NA, Lucena CAS, Malabarba MCSL, Lucena ZMS, Reis RE, Langeani F, Cassati L, Bertaco VA, Moreira C, Lucinda PHF. Genera incertae sedis in Characidae. In: Reis RE, Kullander SO, Ferraris Jr. CJ, organizers. Check list of the freshwater fishes of South and Central America. Porto Alegre: Edipucrs; 2003. p.106-169.

Manchado M, Zuasti E, Cross I, Merlo A, Infante C, Rebordinos L. Molecular characterization and chromosomal mapping of the 5S rRNA gene in Solea senegalensis: a new linkage to the U1, U2, and U5 small nuclear RNA genes. Genome [serial on internet]. 2006; 49(1):79-86. https://doi.org/10.1139/g05-068

Nakajima RT, Cabral-de-Mello DC, Valente GT, Venere PC, Martins C. Evolutionary dynamics of rRNA gene clusters in cichlid fish. BMC Evol Biol [serial on internet]. 2012; 12(198):1-11.Available from: https://doi.org/10.1186/14712148-12-198

Nishiyama PB, Rossi MMV, Porto FE, Borin LA, Portela-Castro ALB, Martins-Santos I. CIC. Cytogenetic studies in species of stream fishes: Hyphessobrycon vinaceus, Bryconamericus aff. iheringii and Odontostilbe pequira (Pisces: Characidae). Evolução e Conservação da Biodiversidade. 2015; 6(1):13-22.

Oliveira C, Avelino GS, Abe KT, Mariguela TC, Benine RC, Ortí G, Vari RP, Corrêa e Castro RM. Phylogenetic relationships within the speciose family Characidae (Teleostei: Ostariophysi: Characiformes) based on multilocus analysis and extensive ingroup sampling. BMC Evol Biol [serial on internet]. 2011; 11(275):1-25. Available from: https://doi.org/10.1186/14712148-11-275

Paintner-Marques TR, Giuliano-Caetano L, Dias AL. Multiple NORs in Bryconamericus aff. exodon (Osteichthyes, Characidae, Tetragonopterinae). Hereditas. 2002; 137(2):107-12. 
Paintner-Marques TR, Giuliano-Caetano L, Dias AL. Cytogenetic characterization of a population of Bryconamericus aff. iheringii (Characidae, Tetragonopterinae). Genet Mol Biol. 2003; 26(2):145-49.

Pazian MF, Pereira LHG, Shimabukuru-Dias CK, Oliveira C, Foresti F. Cytogenetic and molecular markers reveal the complexity of the genus Piabina Reinhardt, 1867 (Characiformes: Characidae). Neotrop Ichthyol. 2012; 10(2):329-40.

Pelliccia F, Barzotti R, Bucciarelli E, Rocchi A. 5S ribosomal and U1 small nuclear RNA genes: a new linkage type in the genome of a crustacean that has three different tandemly repeated units containing 5S ribosomal DNA sequences. Genome [serial on internet]. 2001; 44(3):331-35. Available from: https://doi. org/10.1139/g01-012

Peres WAM., WAM, Bertollo LAC, Moreira-Filho O. Physical mapping of the $18 \mathrm{~S}$ and $5 \mathrm{~S}$ ribosomal genes in nine Characidae species (Teleostei, Characiformes). Genet Mol Biol. 2008; 31(1):222-26.

Pendás AM, Morán P, Freije JP, Garcia-Vásquez E. Chromosomal mapping and nucleotide sequence of two tandem repeats of the Atlantic salmon 5S rDNA. Cytogenet Cell Genet [serial on internet]. 1994; 67(10):31-36. Available from: https://doi. org/10.1159/000133792

Pinkel D, Straume T, Gray JW. Cytogenetic analysis using quantitative, high-sensitivity, fluorescence hybridization. Proc Natl Acad Sci USA. 1986; 83(9):2934-38. Available from: https:/www.ncbi.nlm.nih.gov/pmc/articles/PMC323421/

Piscor D, Ribacinko-Piscor DB, Fernandes CA, Parise-Maltempi PP. Cytogenetic analysis in three Bryconamericus species (Characiformes, Characidae): first description of the 5S rDNAbearing chromosome pairs in the genus. Mol Cytogenet [serial on internet]. 2013; 6(13):1-8. Available from: https://doi. org/10.1186/1755-8166-6-13

Piscor D, Centofante L, Parise-Maltempi PP. Highly similar morphologies between chromosomes bearing U2 snRNA gene clusters in the group Astyanax Baird and Girard, 1854 (Characiformes, Characidae): an evolutionary approach in species with $2 \mathrm{n}=36,46,48$, and 50 . Zebrafish [serial on internet]. 2016; 13(6):565-70. Available from: https://doi. org/10.1089/zeb.2016.1292

Piscor D, Parise-Maltempi PP. Microsatellite organization in the B chromosome and A chromosome complement in Astyanax (Characiformes, Characidae) species. Cytogenet Genome Res [serial on internet]. 2016; 148(1):44-51. Available from: https://doi.org/10.1159/000444728

Piscor D, Fernandes CA, Parise-Maltempi PP. Nucleolar organizer regions, $18 \mathrm{~S}$ and $5 \mathrm{~S}$ rDNA clusters in the chromosomes of Piabina argentea (Characiformes, Characidae). Biologia. 2017; 72(12):1499-502. Available from: https://doi.org/10.1515/ biolog-2017-0162

Sambrook J, Russell DW. Molecular cloning: a laboratory manual. 3th ed. New York: Cold Spring Harbor Laboratory Press; 2001.

Santos AR, Rubert M, Giuliano-Caetano L, Dias AL. Sympatric occurrence of four cytotypes and one extra chromosome in Bryconamericus ecai (Characidae): 18S rDNA polymorphism and heterochromatin composition. Hereditas. 2012; 149(1):24-33.

SantosARD, Usso MC, Gouveia JG, Araya-JaimeC, Frantine-Silva W, Giuliano-Caetano L, Foresti F, Dias AL. Chromosomal mapping of repetitive DNA sequences in the genus Bryconamericus (Characidae) and DNA barcoding to differentiate populations. Zebrafish [serial on internet]. 2017; 14(3):261-71. Available from: https://doi.org/10.1089/zeb.2016.1380
Scacchetti PC, Utsunomia R, Pansonato-Alves JC, Vicari MR, Artoni RF, Oliveira C, Foresti, F. Chromosomal mapping of repetitive DNAs in Characidium (Teleostei, Characiformes): genomic organization and diversification of ZW sex chromosomes. Cytogenet Genome Res [serial on internet]. 2015; 146(2):13643. Available from: https://doi.org/10.1159/000437165

Schweizer D, Loidl J. A model for heterochromatin dispersion and the evolution of C-band patterns. In: Stahl A, Luciani JM, Vagner-Copodano AM, editors. Chromosomes Today. Dordrecht (ZH): Springer; 1987. p.61-74. Available from: https://doi.org/10.1007/978-94-010-9166-4_7

Silva LLL, Giuliano-Caetano L, Dias AL. Karyotypic diversity in a population of Bryconamericus aff. iheringii (Characidae). Genet Mol Res. 2014; 13(1):2069-81.

Silva DMZA, Utsunomia R, Pansonato-Alves JC, Oliveira C, Foresti F. Chromosomal mapping of repetitive DNA sequences in five species of Astyanax (Characiformes, Characidae) reveals independent location of U1 and U2 snRNA sites and association of U1 snRNA and 5S rDNA. Cytogenet Genome Res [serial on internet]. 2015; 146(2):144-52. Available from: https://doi.org/10.1159/000438813

Supiwong W, Liehr T, Cioffi MB, Chaveerach A, Kosyakova N, Pinthong K, Tanee T, Tanomtong A. Karyotype and cytogenetic mapping of 9 classes of repetitive DNAs in the genome of the naked catfish Mystus bocourti (Siluriformes, Bagridae). Mol Cytogenet. 2013; 6(51):1-7. Available from: https://doi. org/10.1186/1755-8166-6-51

Thomaz AT, Arcila D, Ortí G, Malabarba LR. Molecular phylogeny of the subfamily Stevardiinae Gill, 1858 (Characiformes: Characidae): classification and the evolution of reproductive traits. BMC Evol Biol [serial on internet]. 2015; 15(146):1-25. Available from: https://doi.org/10.1186/s12862-015-0403-4

Úbeda-Manzanaro M, Merlo MA, Palazón JL, Cross I, Sarasquete C, Rebordinos L. Chromosomal mapping of the major and minor ribosomal genes, (GATA) ${ }_{n}$ and U2 snRNA gene by double-color FISH in species of the Batrachoididae family. Genetica [serial on internet]. 2010; 138(7):787-94. Available from: https://doi.org/10.1007/s10709-010-9460-1

Utsunomia R, Scacchetti PC, Pansonato-Alves JC, Oliveira C, Foresti F. Comparative chromosome mapping of U2 snRNA and 5S rRNA genes in Gymnotus species (Gymnotiformes, Gymnotidae): evolutionary dynamics and sex chromosome linkage in $G$. pantanal. Cytogenet Genome Res [serial on internet]. 2014; 142(4):286-92. Available from: https://doi. org/10.1159/000362258

Yano CF, Bertollo LA, Rebordinos L, Merlo MA, Liehr T, PortelaBens S, Cioffi MB. Evolutionary Dynamics of rDNAs and U2 Small Nuclear DNAs in Triportheus (Characiformes, Triportheidae): High Variability and Particular Syntenic Organization. Zebrafish [serial on internet]. 2017; 14(2):14654. Available from: https://doi.org/10.1089/zeb.2016.1351 
